\title{
Development of cleft children's permanent canines
}

\author{
Desenvolvimento dos caninos permanentes de crianças fissuradas
}

\author{
Manoel Itaguacy Leite NOVAIS JUNIOR ${ }^{1}$ iD 0000-0003-2673-0389 \\ Manuella Santos Carneiro ALMEIDA ${ }^{1}$ iD 0000-0002-5849-6972 \\ Camila Helena Machado da COSTA ${ }^{1}$ iD 0000-0002-1340-4042 \\ Tassia Cristina de Almeida Pinto SARMENTO' ${ }^{1}$ (ID) 0000-0002-2789-1507 \\ Luis Ferreira de SOUSA FILHO² ID 0000-0002-9699-0998 \\ Rosa Helena Wanderley LACERDA ${ }^{3}$ iD 0000-0003-0011-6487
}

\section{ABSTRACT}

Objective: Evaluating the development of the permanent cuspids in children from Paraíba with cleft lip and palate applying the Nolla and the Demirjian methods. Methods: A cross-sectional study using an inductive approach and applying a comparative statistical procedure and direct documentation research technique. The universe of the study consisted of children assisted at the orthodontic practice of the Brazilian Association of Dentistry - Paraíba Section. The sample comprised 72 pairs of panoramic radiographs of children with and without cleft lip and palate from the same gender and, age difference of up to 30 days, ranging from 5 to 13 years of age. The study has evaluated the development of 576 cuspids. The images were evaluated by three duly calibrated examiners concomitantly, and the calcification stages were determined by a consensus. The stages of the cuspids calcification were evaluated in the panoramic radiographs according to Nolla and Demirjian classifications. Results: The average of the calcification stage of teeth was correspondingly higher in the control group than in the case group, showing a development delay of the cuspid teeth in the cleft lip and palate patients. The lower cuspids were significantly more developed than the upper cuspids $(p<0.001)$. There were no significant differences between the sides. There was early tooth development in females but without significant difference. Conclusion: It was possible to note that patients with cleft lip and palate presented a delay in the development of the permanent cuspids when compared to non-cleft lip and palate patients, thus, reinforcing the importance of the individualization of the orthodontic planning.

Indexing terms: Cleft lip. Cleft palate. Pediatric dentistry.

\section{RESUMO}

Objetivo: Avaliar o desenvolvimento dos caninos permanentes de crianças da Paraíba com fissura labiopalatina utilizando os métodos de Nolla e Demirjian. Métodos: Estudo transversal, realizado utilizando uma abordagem indutiva com procedimento estatístico comparativo e técnica de pesquisa por documentação direta. O universo consistiu de todas as crianças atendidas no serviço de ortodontia

$\boldsymbol{\nabla} \boldsymbol{\nabla} \boldsymbol{\nabla}$

1 Universidade Federal de Campina Grande, Centro de Saúde e Tecnologia Rural, Unidade Acadêmica de Ciências /Biológicas. Av. Universitários, s/n., Rod. Patos/Teixeira, Km 1, Santa Cecília, 58700-970, Patos, PB, Brasil. Correspondência para / Correspondence to: MIL NOVAIS JUNIOR. E-mail: <itaguacynovais@gmail.com>.

2 Universidade Federal da Paraíba, Centro de Ciências Médicas. João Pessoa, PB, Brasil.

3 Associação Brasileira de Odontologia - Secção Paraíba, Serviço de Ortodontia a pacientes fissurados. João Pessoa, PB, Brasil.

$\boldsymbol{\nabla} \mathbf{v} \mathbf{v}$

How to cite this article

Novais Junior MIL, Almeida MSC, Costa CHM, Sarmento TCAP, Sousa Filho LF, Lacerda RHW. Development of cleft children's permanent canines. RGO, Rev Gaúch Odontol. 2019;67: e20190025. http://dx.doi.org/10.1590/1981-86372019000253520 
da Associação Brasileira de Odontologia - Secção Paraíba. A amostra foi composta por 72 pares de radiografias panorâmicas de crianças com e sem fissura labiopalatina, de mesmo gênero e com diferença de idade de até 30 dias, na faixa etária dos 5 aos 13 anos. Assim, foi avaliado o desenvolvimento de 576 dentes caninos. Todas as imagens foram avaliadas por três examinadores devidamente calibrados, ao mesmo tempo, e os estágios de calcificação foram determinados mediante consenso. Nas radiografias panorâmicas foram avaliados os graus de calcificação dos dentes caninos de acordo com a classificação de Nolla e Demirjian. Resultados: As médias dos estágios de calcificação foram correspondentemente mais elevadas no grupo caso do que no grupo controle, mostrando atraso de desenvolvimento dos dentes caninos nos pacientes fissurados. Os caninos inferiores apresentaram-se significativamente mais adiantados em relação aos superiores $(p<0,001)$. Não foram registradas diferenças significativas entre os lados. 0 desenvolvimento dentário ocorreu precocemente no sexo feminino, mas sem diferença significativa. Conclusão: Desta forma, o presente estudo vem colaborar para o aprimoramento dos conhecimentos acerca do desenvolvimento morfológico dos caninos permanentes nos pacientes fissurados. É consolidada a importância da individualização no planejamento ortodôntico, considerando a grande variação e importância do dente canino, tanto no aspecto funcional, como estético.

Termos de indexação: Fissura palatina. Fenda labial. Odontopediatria.

\section{INTRODUCTION}

The physiological age of a person is determined by the maturation stages of the several tissues of the human body. Thus, such an age can be subdivided into some biological categories, including: skeletal age, morphological age, secondary sexual characteristics and dental age [1].

Age estimation has been more efficient by the evaluation of the stages of tooth development than by the observation of dental eruption, since the latter is influenced by several environmental factors such as early extraction of the deciduous teeth, ectopic position of teeth, extended retention of the deciduous teeth and ankyloses $[2,3]$. The evaluation of dental development is one of the most reliable methods to estimate age and is widely applied to assess the maturity and calculate the chronological age [4].

For the identification and the evaluation of the dental age, direct and indirect examinations can be performed. The first is performed by clinical exams, verifying the number of erupted teeth, eruptive sequence and overall tooth condition [1]. The indirect examination is performed by the analysis of intra and extraoral radiographs. Panoramic radiographs are necessary to classify the cycle and the code of tooth formation according to the previously established stages, such as the methodologies proposed by Nolla [5] and Demirjian, Goldstein and Tanner [6]. This is a very useful technique as it is extraoral and low cost, demanding shorter time and making it possible to evaluate the maxillomandibular region with lower radiation dose [7].

Despite its unquestionable contribution to the process of the chronological identification of the human development, dental development is likely to be influenced by factors such as: ethnic group, gender, eating habits, systemic diseases, infectious processes, climate and constitutional types. Changes in dental development may be related to orofacial fissures such as cleft lip, cleft palate or both associated fissures [8]. The cuspids development is of great importance, as these teeth provide stability to the occlusion, necessary for the lateral movements, being an element of protection to the stomatognathic system, besides being responsible for the occlusal harmony and function [9].

In the literature, there is no data reporting on the cuspids development alone in patients with cleft lip and palate. Therefore, since no studies reporting on this approach were carried out in the Brazilian population, this research study aimed comparing the development of the permanent cuspids in children, from Paraíba, with and without cleft lip and palate, applying the Nolla [5] and the Demirjian [6] methods concurrently.

\section{METHODS}

This cross-sectional study was conducted using an inductive approach and applying a comparative statistical procedure and direct documentation research technique. The research project was approved by the Research Ethics Committee, via Plataforma Brasil (CAAE 23683913.0.0000.5181).

The universe of this study consisted of children assisted at the orthodontic practice of the Brazilian Association of Dentistry - Paraíba Section. The sample comprised 72 pairs of panoramic radiographs of children with and without cleft lip and palate from the same gender and with age difference of up to 30 days, ranging from 5 to 13 years of age. Participated into this study children with no syndromes, systemic diseases or any other orofacial fissures. Such children should also have digital files with 
complete data, raging from 5 - 13 years of age from both sexes, with panoramic radiographs with good image quality and showing all the permanent cuspids. Patients whose radiographs had image issues in the area to be evaluated were excluded from the sample.

The panoramic radiographs from the Brazilian Dental Association, Paraíba Section, were taken at the same Dental Radiology service. The panoramic radiographs were obtained using the Panoramic Digital X-ray unit Instrumentarium Orthopantomograph OP100 $D ®$ (Instrumentarium Corp., Imaging Division, Tuusula, Finland) operating at 13 seconds, $10 \mathrm{~mA}$ and kilovoltage according to the patient's age, weight and density.

The evaluation was carried out by three duly calibrated examiners. For the calibration, 20 digital panoramic radiographs that were not part of the sample were used. The calibration took two weeks and, to ensure the study reproducibility, the analysis of the intra and interexaminer concordance was made applying the weighted kappa test. After obtaining a positive result, the evaluation was started. The panoramic radiographs were masked so that the patient data did not influence the evaluation. Digital image files were numbered and, only when the evaluations were finished, the examiners could access the exam identification and the patient data.

For each method applied, the three examiners, previously calibrated, evaluated the radiographic images concomitantly, and the cuspids calcification stages were chosen by consensus. The evaluation took place in a darkened environment using a 23" screen monitor and the Windows ${ }^{\circledR}$ Picture and Fax Viewer program (Windows $X P)$. The examiners used the zoom tool with a maximum of three- times magnification not to distort the image.

The Demirjian method encodes tooth formation in eight stages, from $A$ to $H$, from the onset of the first calcified point to the apical root closure. Furthermore, Nolla has proposed a classification for dental development comprising eleven stages $(0,1,2,3,4,5,6,7,8,9,10)$, ranging from crypt absence to apical closure.

Each cuspid tooth (13, 23, 33 and 43) was classified according to the stages proposed by the aforementioned methods. In the data analysis, absolute distributions, percentages and statistical measures were obtained. For the statistical measures, encodings were applied for the stages of dental calcification. For the Demirjian method, the following numbering was considered: 1 for stage $A, 2$ for stage B, 3 for stage $C$ and so on. For the Nolla method, the score coding was based on the scale numbering, so 1 was used for stage 1, 2 for stage 2 and so on. For the comparison between the groups, the Mann-Whitney test and the Wilcoxon test for paired data were used when considering the sum of the numerical coding.

The margin of error was $5 \%$ for the statistical tests and the software used was the SPSS (Statistical Package for the Social Sciences) version 21.

\section{RESULTS}

The sample comprised 72 pairs of panoramic radiographs, being $56(77.7 \%)$ from male subjects and 16 (22.3\%) from female subjects. Thus, the dental development of 576 cuspids was evaluated.

Significant differences were seen in the mineralization stages in each method and tooth when comparing the two groups. Evaluating the permanent cuspid teeth in the cleft lip and palate group by the Demirjian method, it was verified that the calcification stage " $E$ " was the most frequent (the percentage ranged from $36.1 \%$ to $44.4 \%$ ), while in the non-cleft lip and palate group, the " $\mathrm{F}$ " stage was the most frequent in the four teeth (the percentage ranged from $33.3 \%$ to $37.5 \%)$. The highest percentage difference between the case and the control groups was seen in the " $\mathrm{H}$ " stage (the difference between groups ranged from 5\% to $7 \%$ ). Applying the Nolla methodology in the cleft lip and palate group, the highest frequencies were seen in stage " 7 " (the percentage ranged from $36.1 \%$ to $44.4 \%$ ), while in the non-cleft lip and palate group, the highest frequencies were seen in stage "8" (ranging from 33.3\% to 37.5\%). Significant differences were seen between the two groups $(p<0.001)$ in each cuspid tooth and method applied.

After applying the encoding for the calcification stages of the Nolla and the Demirjian methods, the age average for the case and the control groups are shown in Table 1. The average age was higher in the non-cleft lip and palate group than in the cleft lip and palate group, with significant difference $(p<0.05)$ in all the permanent cuspid teeth. Additionally, the average age was higher when applying the Nolla method than when applying the Demirjian method in each one of the cuspid teeth and, also, in the cuspids $(13,23,33$ and 43$)$ together. 
Table 1. Statistics of the calcification stages by method applied according to the tooth. João Pessoa (PB), 2017.

\begin{tabular}{|c|c|c|c|c|}
\hline \multirow{2}{*}{ Tooth } & \multirow{2}{*}{$\begin{array}{l}\text { Calcification } \\
\text { Method }\end{array}$} & \multicolumn{2}{|c|}{ Group } & \multirow{2}{*}{ P Value } \\
\hline & & Mean \pm SD (Mean) & Mean \pm SD (Mean) & \\
\hline \multicolumn{5}{|l|}{ Tooth } \\
\hline 13 & Dermijian & $5.45 \pm 0.84(5.00)$ & $5.87 \pm 1.00(6.00)$ & $\mathrm{p}^{(1)}<0.001^{*}$ \\
\hline \multirow[t]{2}{*}{23} & Dermijian & $5.49 \pm 0.88(5.00)$ & $5.90 \pm 1.00(6.00)$ & $\mathrm{p}^{(1)}<0.001^{*}$ \\
\hline & Nolla & $7.49 \pm 0.88(7.00)$ & $7.90 \pm 1.00(8.00)$ & $\mathrm{p}^{(1)}<0.001^{*}$ \\
\hline 33 & Dermijian & $5.76 \pm 0.91(6.00)$ & $6.11 \pm 1.04(6.00)$ & $\mathrm{p}^{(1)}<0.001^{*}$ \\
\hline 43 & Nolla & $7.74 \pm 0.96(8.00)$ & $8.08 \pm 1.04(8.00)$ & $\mathrm{p}^{(1)}=0.001^{*}$ \\
\hline \multirow[t]{2}{*}{$\begin{array}{l}\text { Cuspids } \\
(13,23,33,43)\end{array}$} & Dermijian & $5.61 \pm 0.91(6.00)$ & $5.99 \pm 1.02(6.00)$ & $\mathrm{p}^{(1)}<0.001^{*}$ \\
\hline & Nolla & $7.61 \pm 0.91(8.00)$ & $7.99 \pm 1.03(8.00)$ & $\mathrm{p}^{(1)}<0.001^{*}$ \\
\hline
\end{tabular}

Note: ${ }^{\star *}: 5,0 \%$ Significant difference. ${ }^{(1)}$ : Through the Wilcoxon test for paired data.

Table 2. Statistics of the calcification stages by method applied according to the side and the group. João Pessoa (PB), 2017.

\begin{tabular}{|c|c|c|c|c|}
\hline \multirow{2}{*}{ Tooth } & Method/Side & \multicolumn{2}{|c|}{ Group } & \multirow{2}{*}{ P Value } \\
\hline & & Mean \pm SD (Mean) & Mean \pm SD (Mean) & \\
\hline \multirow[t]{7}{*}{ Cuspids } & Dermijiam & & & \\
\hline & Right & $5.59 \pm 0.91(5.00)$ & $5.97 \pm 1.02(6.00)$ & $\mathrm{p}^{(1)}<0.001^{*}$ \\
\hline & Left & $5.63 \pm 0.90(6.00)$ & $6.00 \pm 1.02(6.00)$ & $\mathrm{p}^{(1)}<0.001^{*}$ \\
\hline & Nolla & & & \\
\hline & Right & $7.59 \pm 0.91(7.00)$ & $7.97 \pm 1.03(8.00)$ & $\mathrm{p}^{(1)}<0.001^{*}$ \\
\hline & Left & $7.63 \pm 0.90(8.00)$ & $8.00 \pm 1.02(8.00)$ & $\mathrm{p}^{(1)}<0.001^{*}$ \\
\hline & $P$ value & $\mathrm{p}^{(2)}=0.332$ & $\mathrm{p}^{(2)}=0.180$ & \\
\hline
\end{tabular}

Note: ${ }^{(*)}$ : 5,0\% Significant difference. ${ }^{(1)}$ : Through the Wilcoxon test for paired data for comparison between the groups in each side. (2): Through the Wilcoxon test for paired data for comparison between the sides in each group.

Table 2 shows that there were no significant differences between the right and left sides when evaluating the cuspid teeth in both the cleft and non-cleft lip and palate patients. Additionally, it was verified that the mean values were correspondingly higher in the non-cleft lip and palate group than in the cleft lip and palate group, presenting significant differences.

Table 3 shows that there were significant differences in the development of the lower and the upper cuspid teeth, showing that the average age was 
Table 3. Statistics of the calcification stages by method applied according to the dental arch and group. João Pessoa (PB), 2017.

\begin{tabular}{|c|c|c|c|c|}
\hline \multirow{3}{*}{ Tooth } & \multirow{3}{*}{ Method/Dental Arch } & \multicolumn{2}{|c|}{ Group } & \multirow{3}{*}{$P$ value } \\
\hline & & Cleft & Non-Cleft & \\
\hline & & Mean \pm SD (Mean) & Mean \pm SD (Mean) & \\
\hline \multirow[t]{8}{*}{ Cuspids } & Dermijiam & & & \\
\hline & Upper & $5.47 \pm 0.85(5.00)$ & $5.88 \pm 0.99(6.00)$ & $\mathrm{p}^{(1)}<0.001^{*}$ \\
\hline & Lower & $5.75 \pm 0.93(6.00)$ & $6.10 \pm 1.04(6.00)$ & $\mathrm{p}^{(1)}<0.001^{*}$ \\
\hline & $P$ value & $\mathrm{p}^{(2)}<0.001^{*}$ & $\mathrm{p}^{(2)}<0.001^{*}$ & \\
\hline & Nolla & & & \\
\hline & Upper & $7.47 \pm 0.85(7.00)$ & $7.87 \pm 1.00(8.00)$ & $\mathrm{p}^{(1)}<0.001^{*}$ \\
\hline & Lower & $7.75 \pm 0.94(8.00)$ & $8.10 \pm 1.04(8.00)$ & $\mathrm{p}^{(1)}<0.001^{*}$ \\
\hline & $P$ value & $\mathrm{p}^{(2)}<0.001^{*}$ & $\mathrm{p}^{(2)}<0.001^{*}$ & \\
\hline
\end{tabular}

Note: ${ }^{(*)}$ : 5,0\% Significant difference. ${ }^{(1)}$ : Through the Wilcoxon test for paired data for the comparison between the groups in each dental arch. ${ }^{(2)}$ : Through the Wilcoxon test for paired data for the comparison between the dental arches in each group.

Table 4. Statistics of the calcification stages of the cuspid teeth individually by method applied according to the gender and group.

\begin{tabular}{|c|c|c|c|c|c|c|c|}
\hline \multirow[b]{2}{*}{ Tooth } & \multirow[b]{2}{*}{ Calcification } & \multicolumn{2}{|c|}{ Cleft } & \multirow[b]{2}{*}{ P Value } & \multicolumn{3}{|c|}{ Non-Cleft } \\
\hline & & Male & Female & & Male & Female & P Value \\
\hline Method & Mean \pm SD (Mean) & $\begin{array}{c}\text { Mean } \pm \text { SD } \\
\text { (Mean) }\end{array}$ & & $\begin{array}{c}\text { Mean } \pm \text { SD } \\
\quad(\text { Mean) }\end{array}$ & $\begin{array}{c}\text { Mean } \pm \text { SD } \\
\text { (Mean) }\end{array}$ & & \\
\hline \multirow[t]{2}{*}{13} & Dermijian & $\begin{array}{c}5.40 \pm 0.90 \\
\quad(5.00)\end{array}$ & $\begin{array}{c}5.50 \pm 0.76 \\
\quad(5.00)\end{array}$ & $\mathrm{p}^{(1)}=0.612$ & $\begin{array}{c}5.80 \pm 0.91 \\
\quad(6.00)\end{array}$ & $\begin{array}{c}5.94 \pm 1.11 \\
\quad(6.00)\end{array}$ & $\mathrm{p}^{(1)}=0.810$ \\
\hline & Nolla & $\begin{array}{c}7.40 \pm 0.90 \\
(7.00)\end{array}$ & $\begin{array}{c}7.50 \pm 0.76 \\
(7.00)\end{array}$ & $p^{(1)}=0.612$ & $\begin{array}{c}7.78 \pm 0.95 \\
(8.00)\end{array}$ & $\begin{array}{c}7.94 \pm 1.11 \\
(8.00)\end{array}$ & $\mathrm{p}^{(1)}=0.741$ \\
\hline \multirow[t]{2}{*}{23} & Dermijian & $\begin{array}{c}5.43 \pm 0.84 \\
\quad(5.00)\end{array}$ & $\begin{array}{c}5.56 \pm 0.91 \\
(5,50)\end{array}$ & $p^{(1)}=0.593$ & $\begin{array}{c}5.83 \pm 0.93 \\
\quad(6.00)\end{array}$ & $\begin{array}{c}5.97 \pm 1.09 \\
(6.00)\end{array}$ & $p^{(1)}=0.733$ \\
\hline & Nolla & $\begin{array}{c}7.43 \pm 0.84 \\
\quad(7.00)\end{array}$ & $\begin{array}{c}7.56 \pm 0.91 \\
\quad(7.50)\end{array}$ & $p^{(1)}=0.593$ & $\begin{array}{c}7.83 \pm 0.93 \\
\quad(8.00)\end{array}$ & $\begin{array}{c}7.97 \pm 1.09 \\
(8.00)\end{array}$ & $p^{(1)}=0.733$ \\
\hline \multirow[t]{2}{*}{33} & Dermijian & $\begin{array}{c}5.53 \pm 0.98 \\
\quad(5.50)\end{array}$ & $\begin{array}{c}5.94 \pm 0.80 \\
(6.00)\end{array}$ & $\mathrm{p}^{(1)}=0.142$ & $\begin{array}{c}6.09 \pm 1.04 \\
(6.00)\end{array}$ & $\begin{array}{c}6.13 \pm 1.06 \\
(6.00)\end{array}$ & $p^{(1)}=0.903$ \\
\hline & Nolla & $\begin{array}{c}7.63 \pm 0.98 \\
(7.50)\end{array}$ & $\begin{array}{c}7.94 \pm 0.80 \\
(8.00)\end{array}$ & $p^{(1)}=0.142$ & $\begin{array}{c}8.09 \pm 1.04 \\
(8.00)\end{array}$ & $\begin{array}{c}8.13 \pm 1.06 \\
(8.00)\end{array}$ & $p^{(1)}=0.903$ \\
\hline 43 & Dermijian & $\begin{array}{c}5.58 \pm 0.98 \\
(5.00)\end{array}$ & $\begin{array}{c}5.94 \pm 0.91 \\
(6.00)\end{array}$ & $\mathrm{p}^{(1)}=0.120$ & $\begin{array}{c}6.08 \pm 1.09 \\
(6.00)\end{array}$ & $\begin{array}{c}6.10 \pm 0.99 \\
(6.00)\end{array}$ & $p^{(1)}=0.982$ \\
\hline Nolla & $7.58 \pm 0.98(7.00)$ & $\begin{array}{c}7.94 \pm 0.91 \\
(8.00)\end{array}$ & $\mathrm{p}^{(1)}=0.120$ & $8.08 \pm 1.09(8.00)$ & $\begin{array}{c}8.12 \pm 0.99 \\
(8.00)\end{array}$ & $p^{(1)}=0.982$ & \\
\hline
\end{tabular}

Note: ${ }^{(1)}$ : Through the Mann-Whitney test.

higher in the lower arch in both groups. In addition, it was also verified a delay in the average age of cleft lip and palate patients when compared to the control group.

\section{DISCUSSION}

Cleft lip and palate is the most frequent congenital craniofacial deformity and occurs in several ways, causing 
anatomical deformation to the upper lip, nose and palate [10]. Among the most common dental characteristics seen in these patients are dental changes in the cleft area and outside them [8], whose severity seems to be directly related to the type of cleft $[11,12]$. The most prevalent dental anomaly in individuals with non-syndromic cleft palate corresponds to dental agenesis, supernumerary teeth, microdontia, ectopic teeth, rotated teeth, taurodontism and enamel hypoplasia [8].

In this current research study, 30 pairs of panoramic radiographs have been excluded, in which seven (23.3\%) pairs were excluded due to cuspids agenesis in the case group, mainly caused by cleft lip and palate, and 23 (76.7\%) pairs were excluded due to improper images, as lack of sharpness in the area to be evaluated. Patients with cleft lip and palate have severe functional and aesthetic disorders. Therefore, to have an effective treatment, it is necessary to have a multidisciplinary team involved as gynecologists, obstetricians, geneticists, plastic surgeons, pediatricians, nutritionists, speech therapists, psychologists and dentists [13]. Regarding the dental treatment, surgical procedures are performed from the first three months of life up to two years of age, initially performing lip and palate reconstructions. In the first year of life, treatment with the otorhinolaryngologist and the speech therapist begins. At the end of adolescence, plastic surgery is performed after the completion of the orthodontic rehabilitation [14].

In this treatment plan, knowing the speed and the percentage of the remaining facial growth is important for the efficacy of the growth-modifying interventions [15]. The methods frequently applied to evaluate the overall growth or physiological age of a person are the determination of the chronological, dental and skeletal ages, as well as the observation of variations in weight and height and the manifestation of the secondary sexual characteristics that follows the preadolescence [16]. Dental development is a further relevant issue for cleft lip and palate patients, given the complexity and the long treatment time to which they are subject. The establishment of the ideal time to start treatment aims at minimizing the amount of procedures to be performed in these patients [17]. The present study has evaluated the mineralization stages of the permanent cuspid teeth in a sample matched by sex and age (clef and non-cleft lip and palate children) applying two methodologies (Nolla and Demirjian). Data obtained may contribute as an indicator of dental maturity for these subjects.
Nur et al. [18] when evaluating the dental age of subjects, have also applied the Demirjian and the Nolla methodologies, confirming their applicability. However, these methodologies have few applications in concurrent evaluations (Nolla and Demirjian) in samples of cleft lip and palate patients and, in none of them, the goal was to evaluate the permanent cuspid teeth alone. Cuspids, besides being relevant to the dental structure and function, their development, adjacent to the fissure, most times, is used as criteria to determine the time to carry out alveolar bone graft, since it is frequent to have missing lateral incisors. However, when this tooth is in place, the same criteria should be applied [19,20].

This study has evaluated 72 pairs of panoramic radiographs, totaling 576 cuspid teeth. Through the results achieved, it was verified that there was a significant difference when comparing the cleft group to the non-cleft lip and palate group, verifying that the cleft lip and palate patients had later calcification stages than the non-cleft lip and palate patients. Corroborating with the results of the current study, Almotairy et al. [21] have also verified late dental development in cleft lip and palate children when compared to the control group. Neves et al. [22] have stated that the time of the permanent dentition formation is longer in cleft lip and palate children than in non-cleft lip and palate children, and that such time increases with the cleft severity. According to Tan et al. [23] many studies suggest that cleft lip and palate children have late dental development and distinct time of tooth pair formation. However, when evaluating a sample of Singaporean patients, these authors have verified that there was no difference in dental maturity between the cleft lip and palate group and the control group in the age range of 9 to 13 years of age, verifying a difference between groups only in the range of 5 to 9 years of age. This result underscores the importance of having regional studies on dental development in these stigmatized patients. In the studies conducted by Nolla [5] and Dhanjal et al. [24], it was verified no significant differences in the mineralization stages between the right and left sides of the non-cleft lip and palate patients. Corroborating this research, no significant differences were seen when evaluating the development of the cuspid teeth in the right and left sides, both in the case group and in the control group. This result is in agreement with Ribeiro et al. [25] and Pioto et al. [26] who, when compared the dental development of the permanent upper lateral incisors in the cleft area, with the 
development of their counterpart, in subjects with cleft lip and unilateral palate, verified a delay in relation to the development of the tooth on the affected side. Considering the evaluation of the dental arches, Nolla [5], Dhanjal et al. [24] and Orhan et al. [27] have reported that the lower teeth were significantly more developed than the upper teeth, similar to what was seen in the present study when applying the Demirjian and the Nolla methods.

Almeida et al. [28] have concluded that female patients have presented earlier mineralization stages than males. Loevy and Aduss [29] have observed advancement of dental age in male subjects. These findings disagree with the ones from the present study, in which the dental development of the cuspids, although occurring earlier in females, presented no significant difference between male and female subjects. Almotairy et al. [21] have also found no sexual dimorphism in the dental development of cleft patients applying the Willems and the Demirjian methods.

\section{CONCLUSION}

In view of the data reported in here, it was verified that subjects with cleft lip and palate have presented late dental development when compared to non-cleft lip and palate patients, thus, reinforcing the need to individualize the orthodontic planning, considering the great variation and relevance of the cuspid teeth for the functional and aesthetic aspects.

Therefore, the present research study has contributed to broaden the knowledge about the morphological development of the cuspid teeth in cleft lip and palate patients, as such patients need extensive and comprehensive treatment for the functional and aesthetic restoration of the orofacial aspect.

\section{Collaborators}

MIL NOVAIS JUNIOR and MSC ALMEIDA, writing. CHM COSTA, data collection and sample selection. TCAP SARMENTO, LF SOUSA FILHO and RHW LACERDA, evaluation.

\section{REFERENCES}

1. Peiris TS, Roberts GJ, Prabhu N. Dental age assessment: a comparison of 4-to 24-years-olds in the United Kingdom and an Australian population. Int J Paediatr Dent. 2009;19(5):367-76. https://doi.org/10.1111/j.1365-263X.2009.00984.x
2. Baghdadi ZD. Dental maturity in Saudi children using the Demirjian method: a comparative study and new prediction models. ISRN Dent. 2013;2013:390314. https://doi.org/10.11 55/2013/390314

3. Galic I, Vodanovic M, Jankovic S, Mihanovic F, Nakas E, Prohic $S$, et al. Dental age estimation on Bosnian-Herzegovinian children aged 6-14 years: evaluation of Chaillet's international maturity standards. J Forensic Leg Med. 2013 Jan;20(1):40-5. https://doi.org/10.1016/j.jflm.2012.04.037

4. El-Bakary AA, Hammad SM, Mohammed F. Dental age estimation in Egyptian children, comparison between two methods. J Forensic Leg Med. 2010 Oct;17(7):363-7. https:// doi.org/10.1016/j.jflm.2010.05.008

5. Nolla CM. The development of permanent teeth. J Dent Child. 1960;(4):254-66.

6. Demirjian A, Goldstein H, Tanner JM. A new system of dental age assessment. Hum Biol. 1973;45(2):211-27.

7. Oliveira MMN, Correia MF, Barata JS. Aspectos relacionados ao emprego da radiografia panorâmica em pacientes infantis. Rev Fac Odontol Porto Alegre. 2006;47(1): 2006.

8. Shapira Y, Lubit E, Kuftinec MM. Hypodontia in children with various types of clefts. Angle Orthod. 2000;70(1):16-21.

9. Tito MA, Rodrigues RMP, Guimarães JP, Guimarães KAG Caninos superiores impactados bilateralmente. RGO, Rev Gaúch Odontol. 2008;5(2):15-19.

10. Buzzo CL. Tratamento cirúrgico da fissura labial pela técnica de Göteborg: seguimento de 7 anos. Rev Bras Cir Plást. 2010;25(2):251-9.

11. Aizenbud D, Camasuvi S, Peled M, Brin I. Congenitally missing teeth in the Israeli cleft population. Cleft Palate Craniofac J. 2005;42(3):314-7. https://doi.org/10.1597/03-126.1

12. Eerens K, Vlietinck R, Heidbuchel K, Van Olmen A, Derom C, Willems $G$. et al. Hypodontia and tooth formation in groups of children with cleft, siblings without cleft, and nonrelated controls. Cleft Palate-Craniofac. J. 2001; 38(4):374-378. https://doi.org/10.1597/1545-1569_2001_038_0374_ hatfig_2.0.co_2

13. Ribeiro EM, Moreira ASCG. Atualização sobre o tratamento multidisciplinar das fissuras labiais e palatinas. Rev Bras Promoção da Saúde. 2005;18:(1).

14. Freitas JADS, Garib DG, Oliveira M, Lauris RDC, Almeida ALPFD, Neves LT, et al. Rehabilitative treatment of cleft lip and palate: experience of the Hospital for Rehabilitation of Craniofacial Anomalies-USP (HRAC-USP)-Part 2: overall aspects. J Appl Oral Sci. 2012; 20(1):9-15. http://dx.doi.org/10. 1590/S1678-77572012000100003

15. Alkhal HA, Wong RWK, Rabie ABM. Correlation between chronological age, cervical vertebral maturation and fishman's skeletal maturity indicators in Southern Chinese. Angle Orthod. 2008;78(4):591-596. http://dx.doi.org/10.2319/0003-3219 (2008)078 [0591:CBCACV]2.0.CO;2

16. Moraes MEL, Medici Filho E, Moraes LC. Surto de crescimento puberal: relação entre mineralização dentária, idade cronológica, idade dentária e idade óssea - método radiográfico. Rev Odontol UNESP. 1998;(27):111-129. 
17. Long Jr RE, Semb G, Shaw WC. Orthodontic treatment of the patient with complete clefts of lip, alveolus, and palate: lessons of the past 60 years. Cleft Palate Craniofac J. 2000;37(6):533/1-533/13.

18. Nur B, Kusgoz A, Bayram M, Celikoglu M, Nur M, Kayipmaz $S$, et al. Validity of Demirjian and Nolla methods for dental age estimation for Northeastern Turkish children aged 5-16 years old. Med Oral Patol Oral Cir Bucal. 2012; 17(5): 871-877. http://dx.doi.org/10.4317/medoral.18034

19. Osawa T, Omura S, Fukuyama E, Matsui Y, Torikai K, Fujita K. Factors influencing secondary alveolar bone grafting in cleft lip and palate patients: prospective analysis using CT image analyzer. Cleft Palate Craniofac J. 2007; (44):286-91. https:// doi.org/10.1597/06-054

20. Tai K, Park JH, Okadakage S, Mori S, Sato Y. Orthodontic treatment for a patient with a unilateral cleft lip and palate and congenitally missing maxillary lateral incisors and left secondpremolar. Am J Orthod Dentofacial Orthop. 2012; 141(3): 363-73. https://doi.org/10.1016/j.ajodo.2010.04.037

21. Almotairy N, Pegelow M. Dental age comparison in patients born with unilateral cleft lip and palate to a control sample using Demirjian and Willems methods. Eur J Orthod. 2018; 40(1):74-81. https://doi.org/10.1093/ejo/cjx031

22. Neves ACC, Patrocínio MC, Leme KP, Tiemi Ui R. Anomalias dentárias em pacientes portadores de fissuras labiopalatinas: revisão de literatura. Rev Biociência. 2002;8(2):75-81.

23. Tan ELY, Kuek MC, Wong HC, Yow M. Longitudinal dental maturation of children with complete unilateral cleft lip and palate: a case-control cohort study. Orthod Craniofac Res. 2017; 20(4):189-195. https://doi.org/10.1111/ocr.12196
24. Dhanjal KS, Bhardwaj MK, Liversidge HM. Reproducibility of radiographic stage assessment of third molars. Forensic Sci Int. 2006;159 Suppl 1:S74-7 https://doi.org/10.1016/j. forsciint.2006.02.020

25. Ribeiro LL, Neves LT, Costa B, Gomide MR. Dental development of permanent lateral incisor in complete unilateral cleft lip and palate. Cleft Palate Craniofac J. 2002;39(2):193-196. https:// doi.org/10.1597/1545-1569_2002_039_0193_ddopli_ 2.0.CO_2

26. Pioto NR, Costa B, Gomide MR. Dental development of the permanent lateral incisor in patients with incomplete and complete unilateral cleft lip. Cleft Palate Craniofac J. 2005 Sep;42(5):517-20. https://doi.org/10.1597/04-045r.1

27. Orhan K, Ozer L, Orhan A I, Dogan S, Paksoy CS. Radiographic evaluation of third molar development in relation to chronological age among Turkish children an youth. Forensic Sci Int. 2007;(165):46-51. https://doi.org/10.1016/j.forsciint. 2006.02.046

28. Almeida MS, Pontual Ados A, Beltrão RT, Beltrão RV, Pontual $\mathrm{ML}$. The chronology of second molar development in Brazilians and its application to forensic age estimation. Imaging Sci Dent. 2013;43(1):1-6. doi: 10.5624/isd.2013.43.1.1.

29. Loevy HT, Aduss H. Tooth maturation in cleft lip, cleft palate, or both. Cleft Palate J. 1988 Oct;25(4):343-7.

Received on: 24/9/2018 Final version resubmitted on: 30/10/2018 Approved on: 29/11/2018 